Nigerian Journal of Physiological Sciences 19(1-2): 53-59 (C) Physiological Society of Nigeria 2004

\title{
INDUCED SECRETION OF PEPSIN-RICH GASTRIC JUICE IN THE RAT BY THE CRUDE EXTRACT FROM ELAEOPHORBIA DRUPIFERA LEAVES: A DUAL PATHWAY MECHANISM
}

\author{
A. E. ENO.; N. AZAH; *E. E. EDET and *E. H. ITAM \\ Departments of Physiology and *Biochemistry, College of Medical Sciences, University of Calabar. \\ Phone: +234 8055664612 E-mail: nkineno@yahoo.co.uk
}

\begin{abstract}
Summary: Ninety male white Wistar rats (200 - 320g) were fasted for 48 hours, and used in the experiments for the collection of gastric juice according to the method of Shay et al, 1954. The extract $(2.5-200 \mathrm{mg} / \mathrm{kg}$ ) increased the secretion of gastric juice which was low in volume but rich in pepsin concentration. The adrenergic drugs dihydroergoergotoxine (hydergine) $(1.25 \mathrm{mg} / \mathrm{kg})$ and phentolamine $(1.5 \mathrm{mg} / \mathrm{kg})$ both also increased gastric secretion, which were high in volume, titratable acidity and total acid output but low in pepsin concentration. When the extract $(20 \mathrm{mg} / \mathrm{kg}) \mathrm{was}$ given in combination with either of the two sympatholytic drugs, the pepsin concentration in the juice was richer than that evoked by either of the two drugs alone. Also, atropine-extract combination significantly $(\mathrm{P}<0.01)$ increased gastric juice secretion when compared to that produced by atropine alone. Similar increase in acid secretion was observed when cimetidine-extract combination was administered and compared to that produced by cimetidine alone. We suggest a dual pathway mechanism of action for the E. drupifera leaf extract-induced secretion of gastric juice. One of which may be mediated by the muscarinic cholinoceptors and the other via histamine $\mathrm{H}_{2}$-receptor subtype.
\end{abstract}

Key Words: Elaeophorbia drupifera; gastric juice, muscarinic- and histaminergic-receptors.

\section{Introduction}

Plants of the family of Euphobiaceae are frequently used in the indigenous system of medicine. Their pharmacological properties include anti-tumor, antibacterial, and hypotensive activities (Schiff, 1970). However, little literature is available on the medicinal uses of the species Elaeophorbia drupifera (Thonn.) Stapf, ("Akpa Mbiet"), although it is listed among the plants that heal (Ampofo, 1977). Ingenol (Kinghom and Evans, 1974; Abo, 1990) and lectins (Lynn and Radford, 1986) have been isolated from the latex of E. drupifera. The fruit is succulent (Kinghorn and Evans, 1974) but the latex has skin irritation effect (Kinghorn and Evans, 1975), and promotes inflammation (Ab0, 1994). The leaf is used as a filaricide and for guinea worm infestation (Comley, 1990). It is said to contain hypoglycaemic agents(s) (Eno and Itam, 1996), and stimulates autonomic cholinoceptors in the rat uterus (Eno and Itam, 1997). The extract has recently been found to moderately inhibit HIV-1 and HIV - 2 proviral and DNA copying (Ayisi and Nyadedzor, 2003).

This local herb is used by traditional herbalists for the treatment of hypertension, diabetes and many other ailments. Ground leaves (paste) are dissolved in either water or soft drink (Coca cola), and administered orally in doses determined by age. Little information about $E$. drupifera leaves is known let alone its sideeffects on gastrointestinal functions, as the drug is administered orally in most cases.

In this study, our aim was to investigate the effect of the extract on gastric juice secretion and content, an important gastrointestinal functions. It is also to elucidate the possible mechanism of action employed by the agent(s) in the extract. The method employed for this study was as described by Shay, et al (1954). This was preferred to the much simpler method of Ghosh and Schild (1958) since it made possible the analysis of gastric juice contents.

\section{Materials and Methods \\ Preparation of the Crude Extract}

Fresh leaves of $E$. drupifera were collected. The crude ethanolic extract was prepared according to the method of Parry et al. (1987).

A starting sample of $50 \mathrm{~g}$ of fresh material gave a mean yield of $1.58 \pm 0.47 \mathrm{~g}( \pm$ SD) of extract $(n=10)$. Weighed samples of 
the extract were then used to make up test solutions of the desired concentrations.

\section{Experimental Procedures}

The gastric juice was collected according to the method of Shay et al (1954) To ensure passage of faeces from the cage, each animal was housed singly in a cage with a raised bottom of wide wire mesh. The animals were fasted 48 hours starting in early morning, to ensure complete emptying of the stomach and water was permitted ad libitum. The animals were weighed immediately before fasting and at the end of the 48 hours fast.

Under light ether anaesthesia, the abdomen of the rats was shaved and a midline incision was made extending $2 \mathrm{~cm}$ downwards from the xyphoid. The junction between the pylorus and the duodenum was picked up gently with a curved probe; while the stomach itself was not disturbed. A pyloric ligature was made using silk thread, care being taken to avoid damage of blood vessels or traction on the stomach. In satisfactorily prepared animals, the abdominal wall was then closed by interrupted sutures. The abdominal wound was cleaned thoroughly with physiological saline, dried and covered with a solution of flexible collodion. The anesthesia was discontinued and the animal usually recovered consciousness within less than $10 \mathrm{~min}$. Four hours later, the animal was again anaesthetized with ether, the abdomen was opened and the oesophagus, pylorus, duodenum and appropriate peritoneal ligaments were clamped. The stomach was removed and washed in physiological saline and dried. An opening was then made along the greater curvature and the gastric juice was drained into a graduated centrifuge tube through a funnel.

The gastric contents of each stomach were analysed individually. After centrifugation (6000g for 5min) the volume of the supernatant and solids were recorded. For the determination of titratable acidity, an aliquot of $0.5 \mathrm{ml}$ was titrated with $0.01 \mathrm{~N} \mathrm{NaOH}$ using an end point of $\mathrm{pH} \quad 7.0$ as determined calorimetrically with phenol red as an indicator (Grossman, 1963). Results are expressed as m-equivalents per liter.

Titratable acid output was calculated as $\mu$ equivalents, by multiplying the volume in $\mathrm{ml}$ by the acid concentration in m-equivalent per liter (Brodie and Hooke, 1971). The results were then divided by four to give output per hour.

The determination of proteolytic activity of gastric secretion was performed using casein as substrate according to the method described by Hawk et al (1960). One $\mathrm{ml}$ from various concentrations of bovine pepsin, ranging from $0.1-1.0 \mathrm{mg} / 100 \mathrm{ml}$ in $0.1 \mathrm{~N} \mathrm{HCl}$, was transferred to a test tube and incubated for 30 min with $3.9 \mathrm{ml}$ of the substrate in a water bath at $37^{\circ} \mathrm{C}$. Then, $10 \mathrm{ml}$ of trichloracetic acid (TCA) was added and the tubes allowed to stand for $10 \mathrm{~min}$ and filtered using Whatman filter paper No. 1. Blanks were made for each concentration by adding $10 \mathrm{ml}$ of TCA before the addition of the enzyme. Duplicate determinations were performed for each enzyme concentration. The optical density of the filtrate was measured at $280 \mathrm{~nm}$ wavelength. For the determination of the proteolytic activity of gastric secretion, the same procedure was followed at a concentration of $2 \%$ of $0.1 \mathrm{~N} \mathrm{HCl}$. A standard curve was constructed from which pepsin content of gastric secretion was determined by extrapolation.

Effect of extract concentration on gastric juice secretion

Ninety male, white wistar rats (200$320 \mathrm{~g}$ ) were fasted for $48 \mathrm{hr}$. (water ad lib.) and used in the experiments for the collection of gastric juice. The rats were divided randomly into nine groups of 10 rats per group. Group I received $0.5 \mathrm{ml}$ saline $(0.9 \% \mathrm{NaCl})$ within 5 min after pyloric ligation by subcutaneous (S.C) injection, as the control group. Each of the remaining eight groups was injected (S.C) with one of the following: 2.5, 5, 10, 20, 40, 80,160 and $200 \mathrm{mg} / \mathrm{kg}$. of the crude extract of E. drupifera within 5 min after pyloric ligation. About $0.2-0.5 \mathrm{ml}$ of the extract was always administered. Collection and analysis of gastric juice contents was by the method of Shay et al; (1954) described above.

Influence of some pharmacological agents on extract-induced secretion of gastric juice.

A total of 120 male white wistar rats (290-320g) were fasted for 48hr. (water ad libitum) and used for the experiments following the procedures described above. The rats were divided randomly into 12 groups of 10 rats per group. The experimental protocol was as described by Mohammed et al (1980). In brief, groups I (Control group) and II received $0.5 \mathrm{ml}$ saline $(0.9 \% \mathrm{NaCl})$ and extract $(20 \mathrm{mg} / \mathrm{kg})$ respectively, within $5 \mathrm{~min}$ after pyloric ligation by subcutaneous (S.C) injection.

Other groups ( $\underline{\mathrm{III}}, \underline{\mathrm{V}}, \underline{\mathrm{VII}}, \underline{\mathrm{IX}} \underline{\mathrm{IX}}$ ) were treated with pharmacological agents like dihydroergotoxine (hydergine), phentolamine, atropine and cimetidine, without the extract. The animals in these groups were injected 
(S.C.) with the drug(s) 45min before the pyloric ligation. In the groups (IV, $\underline{\mathrm{VI}}, \underline{\mathrm{VIII}}$, XII) where the $\operatorname{drug}(\mathrm{s})$ was used in combination with the extract $(20 \mathrm{mg} / \mathrm{kg})$, the drug(s) was injected $45 \mathrm{~min}$ before pyloric ligation and the extract added within 5 min after. Collection and analysis of gastric juice contents was by the method of SHAY et al; (1954) described above.

\section{Results}

The crude extract $(2.5-200 \mathrm{mg} / \mathrm{kg})$ from E. drupifera evoked gastric juice secretion in rats. The gastric juice induced by each does of extract was rich in pepsin content, and there was significant dose-dependent increase in titratable acidity, acid output and pepsin concentration (Table I). Following the injection of either dihydroergotoxine (hydergine) $(0.25 \mathrm{mg} / \mathrm{kg})$ or phentolamine $(1.5 \mathrm{mg} / \mathrm{kg})$, the acid volume, titratable acidity and total acid output were increased.(Table II). However, both drugs (hydergine and phentolamine) significantly decreased the concentration of pepsin $(\mathrm{P}<0.01$; $\mathrm{P}<0.05$; for hydergine and phentolamine respectively). In the hydergine + extract (Group IV) -, and phentolamine + extract (Group VI) - treated rats, the gastric juice were richer in acid and pepsin concentration than either of the two drugs alone (Table II). When compared to the control group, the phentolamine - extract combination was probably more potent than the hydergine - extract combination in the secretion of gastric juice. The acid output and pepsin concentration evoked by phentolamine extract combination were more than that produced by hydergine - extract combination by about $23.9 \pm \quad 3.8 \%$ and $28.6 \pm 5.2 \%$ respectively. In table II, atropine sulphate $(0.3 \mathrm{mg} / \mathrm{kg})$ significantly decreased the titratable acidity and acid output $(\mathrm{P}<0.001)$, but failed to change the acid volume and pepsin concentration significantly when compared to the saline treated group. In the atropine-extract treated rats (Group VIII), there was a significant increase in the acid output and titratable acidity when compared to atropine-treated group (Group VII) $(\mathrm{P}<0.01)$. However, the increase in the titratable acidity and acid output by atropine-extract combination was far less than that evoked by the extract alone.

Table I. Dose-effect relationship.

Effect of extract concentration on the volume and content of gastric juice. Data presents the mean values $\pm \operatorname{sem}(n=10)$

\begin{tabular}{ccccc}
\hline $\begin{array}{c}\text { Extract } \\
\text { Concentration } \\
(\mathrm{mg} / \mathrm{kg})\end{array}$ & $\begin{array}{c}\text { Volume } \\
(\mathrm{ml})\end{array}$ & $\begin{array}{c}\text { Titratable acidity } \\
(\mathrm{m} \text {-equiv/L) }\end{array}$ & $\begin{array}{c}\text { Acid Output } \\
(\mu \text {-equiv/L) }\end{array}$ & $\begin{array}{c}\text { Pepsin } \\
\text { Concentration } \\
(\mathrm{mg} / \mathrm{ml})\end{array}$ \\
\hline Saline & $4.3 \pm 0.5$ & $30.5 \pm 3.7$ & $31.5 \pm 3.2$ & $20.9 \pm 1.5$ \\
2.5 & $3.2 \pm 0.4$ & $32.6 \pm 1.5^{*}$ & $33.7 \pm 2.6^{* *}$ & $24.1 \pm 3.2^{+}$ \\
5.0 & $3.1 \pm 0.2$ & $34.8 \pm 2.6^{*}$ & $36.4 \pm 4.2^{*}$ & $25.2 \pm 4.5^{*}$ \\
10 & $2.3 \pm 0.5$ & $36.7 \pm 0.4^{* *}$ & $38.3 \pm 3.3$ & $29.3 \pm 2.6^{*}$ \\
20 & $2.4 \pm 0.4$ & $39.6 \pm 1.2^{+}$ & $43.2 \pm 4.4^{*}$ & $34.9 \pm 3.3^{+}$ \\
40 & $2.2 \pm 0.3$ & $44.3 \pm 3.3^{*}$ & $45.9 \pm 2.8^{*}$ & $37.2 \pm 1.5^{* *}$ \\
80 & $2.1 \pm 0.5$ & $45.8 \pm 2.5^{+}$ & $48.7 \pm 3.6^{+}$ & $38.0 \pm 1.2^{*}$ \\
160 & $2.3 \pm 0.4$ & $47.9 \pm 1.4^{+}$ & $52.3 \pm 4.2^{*}$ & $38.5 \pm 2.4^{+}$ \\
200 & $2.2 \pm 0.2$ & $48.3 \pm 1.6^{+}$ & $54.8 \pm 3.5^{+}$ & $38.7 \pm 3.2^{+}$ \\
\hline
\end{tabular}

$$
\left({ }^{+} P<0.05\right)\left({ }^{*} P<0.01\right) \quad\left({ }^{* *} P<0.001\right) \text { Significantly different from control }
$$


A. E. Eno et al

Table II: Influence of some pharmacological agents in extract-induced secretion of gastric juice. Data represents mean values \pm S.E.M. $(N=6-10)$ Extract concentration $=20 \mathrm{mg} / \mathrm{Kg} . \mathrm{body}$ weight.

\begin{tabular}{|c|c|c|c|c|c|}
\hline Group & Agents & Volume (ml) & $\begin{array}{c}\text { Titratable Acidity } \\
(\mathrm{m} \text {-equiv/L) }\end{array}$ & $\begin{array}{l}\text { Acid Output } \\
\text { ( } \mu \text {-equiv/L) }\end{array}$ & $\begin{array}{c}\text { Pepsin } \\
\text { Concentration } \\
(\mathrm{mg} / \mathrm{ml})\end{array}$ \\
\hline I & Saline (control) & $4.2 \pm 0.3$ & $31.1 \pm 1.3$ & $36.3 \pm 3.4$ & $21.7 \pm 3.5$ \\
\hline II & $\begin{array}{c}\text { Extract } \\
(20 \mathrm{mg} / \mathrm{kg})\end{array}$ & $2.1 \pm 0.2$ & $40.2 \pm 2.2^{+}$ & $8.7 \pm 2.3^{+}$ & $36.1 \pm 1.3^{+}$ \\
\hline III & $\begin{array}{l}\text { Hydergine } \\
(0.25 \mathrm{mg} / \mathrm{kg})\end{array}$ & $5.3 \pm 0.1$ & $48.5 \pm 2.6$ & $74.3 \pm 6.1$ & $15.5 \pm 2.6^{*}$ \\
\hline IV & $\begin{array}{c}\text { Hydergine + } \\
\text { Extract }\end{array}$ & $4.1 \pm 0.2$ & $85.3 \pm 1.3^{+}$ & $80.5 \pm 5.4^{+}$ & $52.1 \pm 1.1 *$ \\
\hline V & $\begin{array}{l}\text { Phentolamine } \\
(2.5 \mathrm{mg} / \mathrm{kg})\end{array}$ & $6.0 \pm 0.4$ & $54.3 \pm 3.1$ & $77.9 \pm 3.9$ & $17.5 \pm 2.9$ \\
\hline VI & $\begin{array}{c}\text { Phentolamine + } \\
\text { Extract }\end{array}$ & $5.4 \pm 0.5$ & $88.9 \pm 2.4^{+}$ & $89.2 \pm 5.2 *$ & $58.3 \pm 1.5^{+}$ \\
\hline VII & $\begin{array}{l}\text { Atropine } \\
(0.3 \mathrm{mg} / \mathrm{kg})\end{array}$ & $4.3 \pm 0.5$ & $15.4 \pm 1.5$ & $18.4 \pm 3.8$ & $19.8 \pm 3.6$ \\
\hline VIII & $\begin{array}{c}\text { Atropine }+ \\
\text { Extract }\end{array}$ & $3.5 \pm 0.4$ & $22.3 \pm 2.5^{*}$ & $20.8 \pm 5.7 *$ & $25.9 \pm 4.7 *$ \\
\hline IX & Cimetidine & $3.6 \pm 0.2$ & $16.2 \pm 3.7$ & $18.9 \pm 3.5$ & $14.5 \pm 3.1$ \\
\hline X & $\begin{array}{c}\text { Cimetidine }+ \\
\text { Extract }\end{array}$ & $4.2 \pm 0.8$ & $23.7 \pm 4.4^{*}$ & $18.9 \pm 3.5^{+}$ & $27.6 \pm 2.9 *$ \\
\hline XI & $\begin{array}{l}\text { Atropine + } \\
\text { Cimetidine }\end{array}$ & $3.7 \pm 0.7$ & $5.6 \pm 4.2$ & $10.3 \pm 0.5$ & $4.2 \pm 1.2$ \\
\hline XII & $\begin{array}{c}\text { Atropine } \\
+ \text { Cimetidine }+ \\
\text { Extract }\end{array}$ & $3.9 \pm 0.6$ & $2.5 \pm 0.7 *$ & $2.9 \pm 1.1^{*}$ & $1.4 \pm 0.9 * *$ \\
\hline
\end{tabular}

Groups II, III,V,VII, IX \& X significantly different from control (Saline treated group).

Group IV signficantly different from III, Group VI significantly different from $V$

Group VIII significantly different from VII; Group X significantly different from IX

Group XII significantly different from IX ${ }^{+} P<0.05 \quad * P<0.01{ }^{* *} P<0.001$

Similarly, in Table II, cimetidine $(0.5 \mathrm{~g} / \mathrm{kg})$ significantly reduced the titratable acidity, acid output as well as the pepsin concentration (Group IX) when compared to the control (saline treated group) $(\mathrm{P}<0.05)$. Following the administration of cimetidine- extract combination (Group X), both the titratable acidity and acid output increased significantly when compared to Group IX $(\mathrm{P}<0.01)$. Table II.

In the group of rats (Group XI) that received both atropine and cimetidine 
combination, the titratable acidity, acid output and pepsin concentration were decreased significantly by $81.9 \pm 5.4 \%, 71.6 \pm 4.8 \%$, and $80.6 \pm 7.2 \%$ respectively when compared to the saline treated group $(\mathrm{P}<0.05)$. Table II). Injection of the extract $(20 \mathrm{mg} / \mathrm{kg})$ to another group that was pretreated with both atropine and cimetidine (Group XII) failed to increase gastric juice secretion. In this group, (Group XII), results showed significant decrease when compared to those of Group XI (combined atropine and cimetidine group).

\section{Discussion}

Maximum stimulation of gastric acid secretion requires the conjoint action of the cholinergic nerves to the secretory cells and gastrin. Also, acid secretion from the parietal cells is strongly stimulated by histamine, whose action is exerted through the $\mathrm{H}_{2}$ receptor subtype (Shamburek and Schubert, 1992). The evidence here is convincing that the crude extract from the leaves of $E$. drupifera possess the property of stimulating the flow of gastric juice in a dose dependent manner. When the crude extract (2.5$200 \mathrm{mg} / \mathrm{kg}$ ) was administered to rats, it induced increased secretion of gastric juice which was low in volume but rich in pepsin concentration, with significant increase in titratable acidity and acid output. The sympatholytic drug, dihydroergotoxine (hydergine), and the nonselective alpha adrenoceptor blocking drug, phentolamine, evoked gastric secretion which were high in volumes, titratable acidity and total acid output. However, the pepsin concentrations evoked by these drugs (hydergine and phentolamine) were low relative to the control (saline treated) group. Phentolamine appeared to be more potent than hydergine in influencing gastric secretion probably due to the manyfold pharmacological effects of hydergine (Bowman and Rand, 1980). In the groups of rats which received either hydergine and the crude extract or phentolamine and the extract, the gastric juice secreted were richer in acid and pepsin concentrations than that evoked by either of the two drugs alone. This supports the view that the extract induces gastric secretion which is rich in pepsin concentration, suggesting increased cephalic or primary phase of gastric secretion (Grijalva and Novin, 1990) It is known that the overactivity of the vagus nerve is manifested by increased gastric acid and pepsin secretion (Tebbe, et al, 2001; Beltran, et al, 1999). Therefore, the significant increase in titratable acidity and pepsin secretion evoked by the extract may be due to parasympathetic stimulation and the release of acetylcholine which is known to stimulate the release of gastric juice rich in acid and pepsin concentration (Schubert and Shamburek, 1990; Konturek, 1982). It is therefore likely that the secretory action of this crude extract was caused by the release of acetylcholine-like agent from the nerve endings to the stomach. Atropine sulphate decreased both the titratable acidity and the acid output (probably by blocking the muscarinic-receptor pathway) but with no change in gastric juice volume or the concentration of pepsin. These results should be expected of a parasympatholytic drug like atropine. However, atropine also stimulates the medulla and higher cerebral centers and this effect is confined to mild excitation of the vagus (Yang, et al, 2002; Ishikawa, et al, 2001). In spite of this result, when atropine was combined with the extract, the mean titratable acidity and acid output were less than that caused by the extract alone. These results suggest that there is an antagonism between atropine and the extract with regards to gastric acid secretion. Blockade of the muscarinic receptor pathway is in line with this contention. Therefore, that atropine-extract combination increased gastric juice secretion when compared to atropine alone, suggests that a different pathway for the stimulant action of the extract is possible, probably the histamine $\mathrm{H}_{2}$-receptor pathway.

Gastric secretion is also blocked by histamine $\mathrm{H}_{2}$-receptor blockers (Schultz, 1979). In the group of rats that received cimetidine alone, the mean titratable acidity, acid output and pepsin concentration were significantly reduced (probably by blocking the histamine $\mathrm{H}_{2}$-receptors and allowing the muscarinic-receptors to predominate) despite the stability in gastric juice volume. When both cimetidine and extract were injected to another group of animals, the titratable acidity, acid output and pepsin concentration were lower than the extract alone, but these values showed significant increases when compared to cimetidine alone. The increased gastric secretion by the cimetidine-extract combination may be mainly due to the operation of the other pathway, that is, the muscarinic receptor pathway. This view is strongly supported by the observation that blockade of both pathways (muscarinic receptor and histamine $\mathrm{H}_{2}$-receptor pathways) with atropine-cimetidine combination almost completely abolished the stimulant action of the extract on gastric acid secretion.

In conclusion, it appears that the crude extract from E. drupifera leaves evoke gastric juice secretion which is rich in pepsin concentration probably by increased cephalic 
phase. High gastric acidity is known to be a factor in the etiology of peptic ulcer. The action of the extract is probably exerted through a dual pathway mechanism. One is via the muscarinic cholinoceptors in which acetylcholine-like agent is the transmitter, and is blocked by atropine. The other pathway is probably via the $\mathrm{H}_{2}$-receptor subtype in which histamine-like agent is the transmitter, and is blocked by the antihistamine, cimetidine. However, the possibility of other receptors being involved is not excluded.

\section{Acknowledgements}

The authors gratefully acknowledge the technical assistance of Mr. D. D. Dakat of the University of Jos, Jos. Nigeria. We also wish to thank the authorities of the University of Jos for permitting the use of their laboratory facilities, and the University of Calabar, Calabar, Nigeria, for the research grant given to Dr. Eno..

\section{References}

Abo, K. A. (1990). Isolation of ingenol from the lattices of Euphorbia and Elaeophorbia species. Fitolterapia. 61 (5): 462-463.

Abo, K. A. (1994). Characterisation of ingenol: am inflammatory diterpene from some Nigerian Euphorbia and Elaeophorbia species. Afri. J. Med Med. Sci. 23 (2): $161-3$.

Ampofo, C. ( 1977). Plants that heal. World Health. 26-30.

Ayisi, N. K. and Nyadedzor, C. (2003). Comparative invitro effects of AZT and extracts of Ocimum gratissimum, Ficus palita, Clausena anisata, Alchornea cordifolia, and Elaeophorbia drupifera against HIV-1 and HIV-2 infections.

Beltran, B; Barrachina, MD; Mendez, A; Quintero, E; Esplugues, J.V. (1999). Synthesis of nitric oxide in the dorsal motor nucleus of the vagus madiates the inhibition of gastric acid secretion by central bombesin. Br. J. Pharmacol. 127:1603-10.

Bowman, W. C and Rand, M. J. (1980). The alimentary canal and drugs used in the treatment of its disorders. In: Textbook of Pharmacology. 2nd. Edn. Blackwell. London. 25: 1-16

Brodie, D. A. and Hooke, K. F. (1971). The effect of vasoactive agents on stressinduced gastric hemorrhage in the rat. Digestion. 4: 193-195.
Comley, J. C. W. (1990). New Macrofilaricidal leads from plants. Trop. Med. Parasitol. 41(1): 1-9.

Eno, A. E. and Itam E. H. (1997). Stimulation of autonomic cholinoceptors in the isolated uterus by the crude extract from Elaeophorbia drupifera leaves. Pharmaceut. Biology. 2: 97-102.

Eno, A. E. and Itam, E. H. (1996). Hypoglycaemic agent(s) in leaves of Elaeophorbia drupifera. Phytotherapy Res. 10: 680-682.

Ghosh, M. N. and Schild, H. O. (1958). Continuous recording of gastric secretion in the rat $\mathrm{Br}$. J. Pharmac. 13: 54-61.

Grijalva, C.V. and Novin, D. (1990). The role of the hypothalamus and dorsal vagal complex in gastrointestinal function and pathophysiology. North Am. 19: 1-25.

Grossman, M. I. (1963) Gastric secretion. Physiol. Physicians 1: 1-3.

Hawk, Ph. B; Oser, B. L. and Summerson, W. H. (1960). In: Practical Physiological Chemistry. Blakidyon. New York. 348352.

Ishikawa, T; Yang, H; Tache, Y. (2001). Microinjection of bombesin into the ventrolateral reticular formatiom inhibits peripherally stimulated gstric acid secretion through spinal pathways in rats. Brain Res. 918: 1-9.

Kinghorn, A. D. and Evans, F. J. (1974). Occurrence of Ingenol in Elaeophorbia species. Planta Medica. 26: 150-154.

Kinghorn, A. D. and Evans, F. J. (1975). The succulent Euphorbias of Nigeria. Lloydia. 38: 363-365.

Konturek, S.J. (1982). Cholinergic control of gastric acid secretion in man. Scand. $J$. Gastroenterol. Suppl. 72:1-5.

Lynn, K. R. and Clevette-Radford, N. A. (1986) Lectins from lattices of Euphorbia and Elaeophorbia species. Phytochemistry. 25: 1553-1557.

Mohammed, A. H; Ahmed, S. El Fikey, M.S. and Ibrahim, M. K. (1980). Gastric secretion and Ulceration induced in the rat by an extract from scorpion telsons. Texicon 18: 619-624.

Parry, O., Okwuasaba, F. K. and Ejike, C. (1987) Skeletal muscle relaxant action of an aqueous extract of Portulaca oleracea in the rat. J. Ethnopharmacol. 19: 247253.

Schiff, P. L. Thalictrum alkaloids. (1970). Lloydia. 33: 403 - 452.

Schubert,, M.L and Shamburek, R.D. (1990). Control of Gastric Secretion. Gastroenterol. Clin. North Am. 19:1-25. 
Gastric juice secretion and Elaaeophorbia drupifera leaves

Shamburek, R.D; Schubert, M.L. (1992). Control of gastric acid secretion. Histamine $\mathrm{H}_{2}$ - receptor antagonists and $\mathrm{H}+\mathrm{K}(+)-$ ATPase inhibitors. Gastroenterolol. Clin. North Am. 21:527550.

Tebbe, J.J; Dietze, T; Grote, C; Monnkes, H. (2001). Excitatory stimulation of neurons in the arcuate nucleus inhibits gastric acid secretion via vagal pathways in anaesthetized rats. Brain Res. 913:10-17.
Yang, H; Tache,Y; Ohning, G; Go, V.L. (2002). Activation of raphe pallidus neurones increases insulin through medullary thyrotropin - releasing hormone (TRH) - vagal pathways. Pancreas. 25: 301-307.

Shay, H; Sun, D.C.H. and Gruenstein, M. (1954). A quantitative method of measuring spontaneous gastric secretion in the rat. Gastroenterology.26: 906.

Received: May 4, 2004

Accepted: October 6, 2004 